\title{
Comment on "Emplacement history and evolution of the Dec- can Volcanic Province, India" by Kale et al. (2020)
}

\author{
Geologist (Retd) Geological Survey of India, Founder Member, Centre for Education and Research in Geosciences (CERG), C2-2, Kumar \\ Classics, Aundh, Pune 411004, Maharashtra India; *Corresponding author, E-mail: Sudha.vaddadi@gmail.com
}

(Received: May 1, 2020; Revised accepted: May 31, 2020)

https://doi.org/10.18814/epiiugs/2020/020068

Deccan Flood basalts have been a subject of studies since the 1967 Koyna earthquake and the understanding of these flood basalts has evolved over several decades during the last and present century. In this context, the meticulous work of field data collection and analysis by the Geological Survey of India (GSI) and other Research Institutions cannot be ignored A huge repository of information on the Deccan Volcanic Province (DVP) exists primarily due to the efforts of put into field mapping by GSI. While appreciating the authors for attempting to compile the vast and diverse information on DVP available in the literature, there are certain inconsistencies and factual errors in the paper. These are being pointed out in the larger interest of the geological community interested in DVP.

In general there is a bias on the part of the authors in data compilation and many of the significant findings by earlier workers/geologists of the Geological Survey of India (GSI), which revolutionised the understanding of Deccan Volcanism, have been ignored by the authors. Besides this, information has been wrongly quoted at places. Moreover, much of the interpretations and suggestions, which the authors claim as theirs, were already addressed by earlier workers. For instance, multiple centres of eruption, probable source of lavas, problems related to long distance correlation, reactivation of faults and fractures as conduits for eruption, emplacement mechanism etc have already been addressed by earlier workers (Chatterjee and Gupta, 2001).

The authors rightly point out that long distance chemical correlation of the lava sequence is not appropriate. This observation has already been made by Misra and others (Misra et al., 2005). The authors also talk about the probable effusive centres and multi-central nature of eruption of Deccan basalts, which were also discussed by earlier workers (Misra et al., 2005).

Kale and others mention that the available data on DVP is lopsided in its geographic coverage of only the western parts of the DVP, with sparse data for almost $75 \%$ of the Province. This is an incorrect statement. The entire state of Maharashtra has been mapped by the GSI on 1:50,000 scale and the data is available with them in digital format.

The authors state that Ray et al. (2008) have recorded xenoliths of basement rocks from the intrusive dykes around Kanherwadi, Chalisgaon and Nandurbar in central part of DVP. Xenoliths of upper crustal granitic rocks in intrusive dykes were recorded from Vakunjhap (near Kanherwadi), Pune and Ahmednagar districts by Sharma and Warrier way back in 1991 and Sharma et al. (1999), much before that documented by Ray et al. (2008). Evidence of pyro-metamorphism in these upper crustal xenoliths was documented by Ghole et al. (2019).

The authors have given comparison of lithostratigraphy and chemostratigraphy and classification from other sub-provinces in Table 1 . There are a few discrepancies in the table. As indicated by the authors, the Kalsubai and Khandala Sub-groups, of Sahyadri Group show good correlation. The equivalence shown in the table is incorrect. The lithostratigraphic classification provided by the authors is based on that given by Godbole et al. (1996). Subsequently, Thorat and Subbarao (1996) have put Alkuti Megacryst/GPB within the Upper Ratangarh Formation, thus introducing an additional Formation namely Middle Ratangarh Formation. This was based on new field data from parts of Pune and Ahmednagar districts, wherein two Megacryst horizons, MC1 and $\mathrm{MC} 2$ were recorded from the thick sequence of pahoehoe flows of Upper Ratangarh Formation. The Megacrysts MC1 and MC2 were later renamed as Alkuti GPB and M3 Megacryst respectively. Alkuti GPB/Megacryst is equivalent to Manchar GPB and M3 Megacryst corre-sponds to Giravali GPB. Obviously, the authors have not updated their data with recent information.

In the section related to stratigraphy and correlation, it is not clear how the authors link Fig. 6 to Fig. 7 and 8. The latter two figures are prepared from the existing DRM (District Resource Maps of GSI, which is on 1:250,000 scale). Mapping of individual flows was done by earlier workers on 1:50,000 scale and this work for the entire state of Maharashtra was completed by 2004. Digital database of the entire state was prepared based on the compilation of these maps. The 1:250,000 scale maps (Quadrangle sheets), were compiled from the original geological maps on 1:50,000 scale, after grouping of the flows based on their morphological and petrological characters. This was the basis for DRMs. While discussing stratigraphy and correlation, the authors should have taken into consideration all the available information in the literature. Verma and Khosla (2019) have also given an overview of the strati-graphic aspects of the DVP, wherein, they have provided a summary of litho-, chemo-, chrono- and magneto-stratigraphies.

The Lithostratigraphy given by the authors for Satpura sub-group, central DVP is incorrect. The Chikli, Buldhana and Karanja Formations are included as part of Kalsubai and Diveghat Sub-groups while the fact is, that they are equivalent of Diveghat, Purandagarh and Mahabalesh-war Formations of Diveghat and Mahabaleshwar Sub- 
Groups (Nair and Bhusari, 2001). This error is also reflected in their earlier paper on stratigraphy and correlation in DVP (Kale et al., 2019). Besides, Nair and Bhusari (2001) in their review of the stratigraphy of Deccan Traps have given different stratigraphic successions for the lava pile in the central DVP in the Satpura, between Narmada and Tapi Rivers. The stratigraphic succession, given in Table 1, for Satpura sub-province, is part of Central DVP, south of Tapi River. This succession actually is for part of Sahyadri Group which comprises the easterly extension of the flows/formations in western Maharashtra. A combined seamless map for the entire state of Maharashtra, covering Western, Central and South-eastern DVP has been prepared by the GSI in 2017. The Sat- pura sub-group, which exposes a maximum of 53 flows, is classified into six Formations, from 1 to 6 (Nair and Bhusari, 2001).

The authors have discussed the emplacement mechanism of lava flows and the processes that operated after the lava was extruded from the edifice. The various changes that take place during the lateral movement of the lava can be better understood, if the network of lava tubes and channels that form the lava plumbing system were taken into consideration. Lava tubes and channels have been documented from DVP by many earlier workers (Sharma and Vaddadi, 1996; Thorat, 1996; Misra et al., 2001; Chatterjee, 2001; Duraiswami, 2004; Sen et al., 2012) and they have recognized the role of lava tubes in the propagation of flows. Studies from active volcanoes in other places suggest that an insulated and thermally efficient lava transport system involving inflated lava sheets, lava tubes and lava channels, can emplace lava flows across great distances (Keszthelyi and Self, 1998). The role of pyroducts in the development of pahoehoe flows can hardly be overstated (Lockwood and Hazlett, 2010).

The authors relate the lobate flows to typical channel-fed pahoehoe flows. Channel-fed flows can also result in A'a flows. Having worked in the DVP, I wish to state that identification of lava tubes and channels is difficult in a dissected lava province like DVP because the entire structure, or all the features of a lava tube, may not be pre-served intact. Hence, what appears as a channel at today's level of ero-sion might have been a tube, with the roof eroded off. One of the ways to decipher probable effusive centres, is by plotting the recorded and confirmed lava channels and tubes in the main DVP and the South Central DVP.

As mentioned in the paper, Chatterjee and Dash (2017) have carried out section measurements, on a larger scale, to bring out the flow architecture. The lateral changes in the flows have been documented by earlier workers of GSI from several areas, and they have attempted correlation only where the flows have been traced laterally. Correlation based on 1:50,000 scale maps is valid to individual flows or sometimes group of flows within a Formation. It is not proper to correlate individual flows on a regional scale. Hence it is difficult to understand how studies based on litholog measurements point to uncertainties in the correlation of the flows on a regional scale.

While it may not be possible for the authors to quote instances of all work done in the past, and that the present authors may have their own choice of interpretation of data and may not agree with the explanations of their predecessors, it is important that significant contributions by earlier workers should be acknowledged in such a publication. In this regard it is regretful that while two of the coauthors in the paper are from GSI, significant work done by officers of GSI since the last two decades has not been mentioned in the paper.
In concluding these comments, I strongly believe that good scientific discourse and contributions to the advancement of Earth science will only be possible only when scientists work together in an unbiased spirit of understanding, acceptance and collaboration.

\section{References}

Chatterjee, A.K., 2001, Petrography and petrochemistry of lava tubes in Gunjale and Mulanagar sectors, Ahmednagar district, Maharashtra. In Roy, A., Bandopadhyay, B.K., Jain, S.C., Nair, K.K.K., Saha, A.K., Misri, J.L., Tiwari, M.P., Rao, K.V., Mohabey, D.M., and Sekhar, S. (Eds) Recent Advances in the field of Earth Sciences and their implications in National Development. Geological Survey of India, Special Publication, v. 64, pp. 511-528.

Chatterjee, K.K., and Gupta, A., 2001, A theoretical approach to emplacement mechanism of Deccan Flood Basalts. In Roy, A., Bandopadhyay, B.K., Jain, S.C., Nair, K.K.K., Saha, A.K., Misri, J.L., Tiwari, M.P., Rao, K.V., Mohabey, D.M., and Sekhar, S. (Eds) Recent Advances in the field of Earth Sciences and their implications in National Development. Geological Survey of India, Special Publication, v. 64, pp. 529541.

Duraiswami, R.A., Bondre, N.R., and Dole G., 2004, Possible lava tube system in a hummocky lava flow at Daund, western Deccan Volcanic Province, India. Proceedings of Indian Academy of Science, v. 113, pp. 813-829.

Ghole, A.N., Marathe, T., and Vaddadi, S., 2019, Textural variation in the crustal xenoliths in basic dykes, Western Deccan Volcanic Province, Maharashtra, India: evidence of partial melting and pyrometamorphism Current Science, v. 117, pp. 1333-1339.

Godbole, S.M., Rana, R.S., and Natu, S.R.,1996, Lava stratigraphy of Deccan basalts of western Maharashtra. In Deshmukh, S.S., and Nair, K.K.K. (Eds) Deccan Basalts, Gondwana Geological Society, Special Publication, v. 2, pp. 125-134.

Kale, V.S., Dole, G., Shandilya Pand Pande, K., 2019, Stratigraphy and correlations in Deccan Volcanic Province, India: Quo vadis? Bulletin, Geological Society of America. v. 132, pp. 588-607.

Keszthelyi, L., and Self, S., 1998, Some physical requirements for the emplacement of long basaltic flows. Journal of Geophysical Research, v. 103, pp. 27447-27464.

Lockwood, J.P., and Hazlett, R.W., 2010, Volcanoes: Global Perspective, Wiley Blackwell, 539p.

Misra, K.S., Sable, A.B., and Bhutani, R., 2001, Lava channels and tubes in the western part of the Deccan Volcanic Province. In Roy, A., Bandopadhyay, B.K., Jain, S.C., Nair, K.K.K., Saha, A.K., Misri, J.L., Tiwari, M.P., Rao, K.V., Mohabey, D.M., and Sekhar, S. (Eds) Recent Advances in the field of Earth Sciences and their implications in National Development. Geological Survey of India, Special Publication, v. 64, pp. 503510 .

Misra, K.S., 2002, Arterial system of lava tubes and channels within Deccan volcanics of western India. Journal Geological Society of India, v. 59 , pp. $115-124$.

Misra, K.S., Bhutani, R., and Sonp, R., 2005, Discussion on "Seismology of Kutch and adjoining region with special reference to 26th January 2001 Earthquake in the vicinity of Bachua, Gujarat. Journal Geological Society of India, v. 66, pp. 379-388.

Nair, K.K.K., and Bhusari, B., 2001, Stratigraphy of Deccan traps: a review. In Roy, A., Bandopadhyay, B.K., Jain, S.C., Nair, K.K.K., Saha, A.K., Misri, J.L., Tiwari, M.P., Rao, K.V., Mohabey, D.M., and Sekhar, S. (Eds) Recent Advances in the field of Earth Sciences and their implications in National Development. Geological Survey of India, Special Publication, v. 64, pp. 477-941.

Sharma, R.K., and Warrier, S., 1991, Geology of parts of Junnar, Ambegaon and Shirur taluka in parts of Pune district and parts of Ahmed- 
nagar district, Maharashtra. Records of Geological Survey of India, v. 124, pp. 82-83.

Sharma, R.K., and Vaddadi, S., 1996, Report on lava tubes/ channels from Deccan Volcanic Province. Gondwana Geological Society, Special Publication, v. 2, pp. 457-460.

Sharma, R.K., Pandit, M.K., and Warrier, S., 1999, Hybrid acid xenoliths in dolerite dykes intruding Deccan Flood Basalts, Pune-Ahmednagar Region, Western India. Gondwana Geological Society, Special Publication, v. 54, pp. 303-308.

Sen, B., Sabale, A.B., and Sukumaran, P.V., 2012, Lava channel of Khedrai Dam, Northeast of Nasik in Western Deccan volcanic province: Detailed morphology and evidences of channel reactivation. Journal of Geological Society of India, v. 80, pp. 314-328. doi:10.1007/ s12594-0120150-8

Thorat P.K., 1996, Occurrence of lava channels and tubes in the western part of Deccan Volcanic Province. In Deshmukh, S.S., and Nair, K.K.K.
(Eds) Deccan Basalts, Gondwana Geological Society, Special Publication, v. 2, pp. 449-456.

Thorat, P.K., and Subbarao, K., 1996, A giant plagioclase basalt from western part of Deccan Trap Province, India. In Deshmukh, S.S., and Nair, K.K.K. (Eds) Deccan Basalts, Gondwana Geological Society, Special Publica-tion, v. 2, pp. 57-73.

Thorat P.K., 2001, Stratigraphic aspects of lava channels and tubes from western parts of the Deccan Volcanic Province. In Roy, A., Bandopadhyay, B.K., Jain, S.C., Nair, K.K.K., Saha, A.K., Misri, J.L., Tiwari, M.P., Rao, K.V., Mohabey, D.M., and Sekhar, S. (Eds) Recent Advances in the field of Earth Sciences and their implications in National Development. Geological Survey of India, Special Publication, v. 64, pp. 493-502.

Verma, O., Khosla, A., 2019, Developments in the stratigraphy of the Dec- can Volcanic Province, peninsular India. Comptesrendus - Geoscience, v. 351, pp. 461-476. doi:10.1016/j.crte.2019.10.002

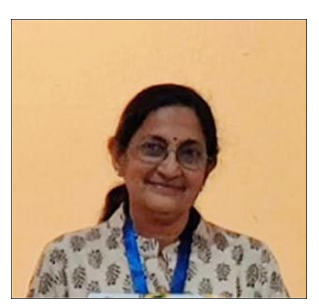

Sudha Vaddadi Sudha Vaddadi obtained her MSc (Geology) from the University of Pune (known now as SPPU), in 1983 and continued as a junior research fellow completing her M. Phil (Geology) in 1985, under the guidance of Prof. A.G.Dessai, from the same University. She obtained her PhD degree in 1999, from the University of Pune, under the guidance of Prof. S.N. Rajaguru. She joined the Geological Survey of India (GSI) in 1986 and worked in various projects in Deccan Volcanic province (DVP) for over 23 years before taking premature retirement in 2009. Sudha Vaddadi is one of the first few geologists from GSI to identify and document lava distributary system (lava channels and tubes) from the DVP in 1989. She has contributed immensely to the creation of a GIS based multilayer spatial database of geological information pertaining to the Western Maharashtra. Post retirement, she has been actively involved in Geoscience education. She is one of the founder members and currently President of the not-for-profit organization, Centre for Education and Research in Geoscience (CERG), Pune, which is aimed at popularizing geoscience among school students and common man at large. She is also associated with the Post Graduate Division of the Department of Geology at Fergusson College, Pune as a visiting faculty since 2010. She has worked in the field of (a) Clay Mineralogy (b) Deccan Volcanics (c) Geomorphology and Morpho-tectonics; Deccan Volcanics being the focus of research. 